\title{
REASONS FOR DISCONTINUATION OF CONTRACEPTIVE METHODS IN PORTSAID CITY
}

\author{
Dr. Seham Shehata Ibrahim, Prof. Sanaa Ali Nor, Nahed Ebrahim Abu Warda \\ Mohammed \\ Obstetrics and Gynecology Nursing-Faculty of Nursing-Port Said University, \\ Professor of Obstetrics and Gynecological Nursing -Faculty of Nursing-Zagazig \\ University, Lecturer of Maternal
}

\begin{abstract}
Background: Most all pregnancies in Egypt are unintended. Of these, a great number occur to women who were practicing contraception in the month they conceived, and others occur when couples stop to use because they find their method difficult or in convenient to use. Objectives: The aim of the study was to assess the reasons for discontinuation of contraceptive methods in Port Said city. Subjects and Methods : This study was conducted at the family planning centers of fife areas which were Al Arab, AL Kewait, Al Manakh, Osman EbnAfan and Omar-Ebn Alkhatab. The study included five hundred women at the reproductive age, who were married, and using or discontinuing use of any contraceptive methods. Results: The results showed that (39.2\%) of the studied women used hormonal contraception before discontinuation, and the reason for its discontinuation was mostly due to side effect(51.7\%) followed by an equal percentage of health problems and husband disapproval (11.1\%). Meanwhile (21.6\%) used IUD before discontinuation and the reason for its discontinuation was mostly due to side effect $(57.4 \%)$ which were mostly due to menstrual irregularities (26.0\%), back or colicky pain (39.0\%) and hyper-menorrhea (35.0\%).Husband' disapproval(28.7\%) and failure of the method(15.1\%) were the main reasons of discontinuation of mechanical barriers. However, the need to switch to another effective method (33.3\%) was the most common reason for discontinuation of natural methods.Recommendation:The study recommended that better training of health providers especially nurses to provide family planning services, better information provision and counseling to clients, particularly about managing side effects and alternative contraceptive methods.
\end{abstract}

Key Words: Natural Family Planning, Oral Contraceptive, Family Planning. 


\section{INTRODUCTION}

Overpopulation and unplanned population growth impede the socioeconomic development, hinder prosperity, and threatens the health status of community members (Basavanthappa, 2008). A woman's ability to space and/or limit her pregnancies has a direct impact on her health and well-being as well as on the outcome of each pregnancy (Andrew J, 2005).

Family planning is a major contributing factor towards child survival and reduction of maternal mortality. The relevance of FP in any strategy for safe motherhood and child survival is undeniable (Littleton-Gibbs LY., etal, 2004). More than 100 million women in the less-developed countries, about $17 \%$ of all married women, would prefer to avoid pregnancy, but are not using any form of FP. Unmet need for contraception can lead to unintended pregnancies, i.e. either unwanted or mistimed, which poses risks for women, their families and society. In the less-developed countries, about one-fourth of pregnancies are unintended (Ashford $\boldsymbol{L}$, 2003). Unintended pregnancy, in recent times, emerged as a crucial public health issue in developing world because it has extensive adverse health, social and economic effects, not only upsetting for the affected mothers and children. Mothers who have mistimed pregnancy are less likely to initiate and utilize prenatal and antenatal care, or seek it later than mothers whose pregnancies are intended. Unplanned pregnancies can also have higher likelihood of low birth weight and unsafe abortion (Jaeni, et al, 2009).

\section{Significance of the study}

Contraceptive discontinuation is one of the recognized risks for low prevalence of contraceptive methods and an important issue in family planning service program. It contributes substantially to the total fertility rate (Westoff, 2006). Until now no study was carried out in Port Said to assess the reasons for discontinuation of contraceptive methods. Thus, the present study was done to determine the key demographic, motivational and service quality characteristics that contribute to contraceptive discontinuation

\section{SUBJECT AND METHODS}

\section{Research design:}

The design of the present study was a descriptive analytic research design 


\section{Settings:}

This study was carried out in 5 family health centers in Port Said, chosen by random selection from all the centers in Port-Said as follows: Al Arab, Al Kewait, El Manakh, Osman Ebn Afan, Omar-Ebn Alkhatab.

\section{Sample:}

The study population consisted of all women attending the study settings who met the following inclusion criteria:

1-At the reproductive age

2-Those users for any type of contraceptive methods and discontinued its use for any reason.

3-Both primipara and multipara were included in the study

\section{Sampling Size}

The sample size was determined according to the following equation:

\section{Z2 X PQ}

Sample Size (n) (Kish \& Leslie,. 1969)

\section{D2}

\section{Tools of Data Collection:}

A structured interviewing (questionnaire sheet) was designed to collect information on the following:

Part1: Socio- demographic Characteristics of the study sample.

Part 2: Medical, menstrual and obstetric history.

Part 3: Reasons for discontinuation of contraceptive methods and intended use of family planning of method.

\section{Operational Design:}

Preparatory phase: During this phase, the researcher reviewed local and international literature to get more knowledge about the study subject. This also helped in designing the study tools. The tools were then prepared and validated through experts' opinions. Test retest reliability was applied by the researcher for testing the internal consistency of the tool.

\section{Administrative Design:}

Before starting any step in the study, an official letter was addressed from the dean of the Faculty of Nursing to the medical directors of the identified study settings, requesting their cooperation and permission to conduct the study. In addition, an oral 
consent was taken from pregnant women in the study, after explaining the purpose and the importance of the research for each of them.

\section{Statistical Design:}

Statistical analysis was done using SPSS 11.0 statistical software packages. Data were presented using descriptive statistics in the form of frequencies and percentages for qualitative variables, in addition to means and standard deviations for quantitative variables. Quantitative continuous data were compared using Student t-test in case of comparisons between two groups. Qualitative variables were compared using chisquare test. The collected data were organized, categorized, tabulated and analyzed using the computer.

\section{RESULTS:}

Table (1): Table 1and Figure 1 show the latest contraceptive method used by women before discontinuation. The most common method used was natural family planning method $(24.0 \%)$ followed by the IUD, mechanical barriers and injectable hormones $(21.6 \%, 15.2 \%$ and $17.2 \%$ respectively).

Table (2): Distribution of the studied women according to their previous use of IUD before discontinuation is demonstrated in table 2. The duration of using the IUD ranged between 1-10 years with a mean of 4.46 43.62 . It was obvious that less than two- thirds $(61.1 \%)$ of women used it from 1-4 years, however, $14.8 \%$ used it for more than 5 years.

Concerning the reasons of discontinuation of using IUD method, 21 women (19.4\%) reported no relation to the method, either the women became pregnant or had infrequent sex $(52.3 \%$ and $47.7 \%$ respectively). On the other hand, the majority of women cited reasons related to the method 87 (80.6\%). Of those, side effects of the IUD were the most common reason, with highest percentage $50(57.4 \%)$ which was mostly due to menstrual irregularities (26.0\%), back or colicky pain (39.0) and hypermenorrhea $(35.0 \%)$. Other reasons given by the women for discontinuation include the need to switch to another method, missed or fallen IUD and husband disapproval $(18.4 \%, 12.7 \%$ and $5.8 \%$ respectively).

Table (3): Distribution of the studied women according to hormonal methods used before discontinuation is demonstrated in table 3. The duration of using the hormonal methods "OCPs, injectable and implants" ranged between 1-14 years. It was obvious 
that less than two- thirds $(62.2 \%)$ of women used it from 1-4 years, however, (3.6\%) used it for more than 10 years.

Table (1): Distribution of the Studied Women According to the Previous Method used for contraception $(n=500)$.

\begin{tabular}{||l|l|l|}
\hline latest method used for contraception $(\mathbf{n = 5 0 0})$ & No. & \% \\
\hline NFP & 120 & 24.0 \\
\hline IUD & 108 & 21.6 \\
\hline INJECTION & 86 & 17.2 \\
\hline MECHANICAL BARRIERS & 76 & 15.2 \\
\hline IMPLANT & 60 & 12.0 \\
\hline PILLS & 50 & 10.0 \\
\hline
\end{tabular}

Figure (1): Distribution of the Studied Women According to the previous method used for contraception $(n=500)$

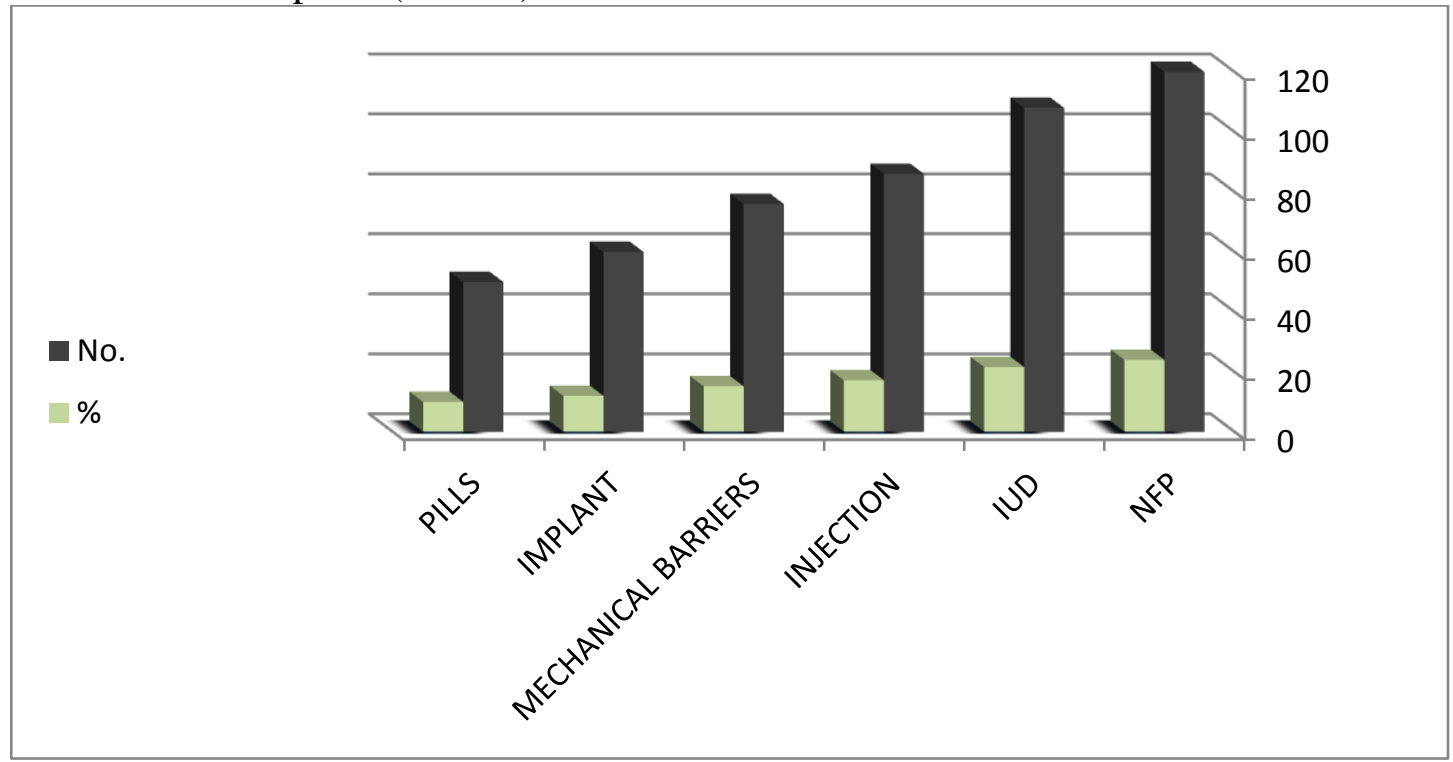


Table (2): Distribution of the Studied Women According to their previous use of IUD before Discontinuation $(n=108)$.

\begin{tabular}{|c|c|c|}
\hline previous Use of IUD Before Discontinuation & No. & $\%$ \\
\hline \multicolumn{3}{|l|}{ 1-Duration of the use of IUD :(n=108) } \\
\hline$>1$ year & 26 & 24.1 \\
\hline $1-4$ years & 66 & 61.1 \\
\hline $5-10$ years & 12 & 11.1 \\
\hline$<10$ years & 4 & 3.7 \\
\hline \multicolumn{3}{|l|}{ 2-The reason to stop using this method: $(\mathrm{n}=108)$} \\
\hline \multicolumn{3}{|l|}{ Reasons not related to the method: $(n=21)$} \\
\hline Want to become pregnancy & 11 & 52.3 \\
\hline $\mathrm{No} /$ infrequent sex-husband is not present & 10 & 47.7 \\
\hline \multicolumn{3}{|l|}{ Reasons related to the method $(\mathrm{n}=87)$} \\
\hline Missed IUD or it fell down & 11 & 12.7 \\
\hline Switch to another method & 16 & 18.4 \\
\hline Side effects & 50 & 57.4 \\
\hline Health concerns & 1 & 1.1 \\
\hline Husband Disapproval & 5 & 5.8 \\
\hline Religious constraint & 4 & 4.6 \\
\hline
\end{tabular}


Table (3): Distribution of the Studied Women According to their previous Use of Hormonal methods before Discontinuation $(n=196)$.

\begin{tabular}{|c|c|c|}
\hline Use of Hormonal methods before Discontinuation & No. & $\%$ \\
\hline \multicolumn{3}{|l|}{ Duration of use of Hormonal methods: $(n=196)$} \\
\hline$>$ a year & 46 & 23.5 \\
\hline $1-4$ & 122 & 62.2 \\
\hline $5-10$ & 21 & 10.7 \\
\hline $10+$ & 7 & 3.6 \\
\hline \multicolumn{3}{|l|}{ The reason to stop using this method:(n=209) } \\
\hline \multicolumn{3}{|l|}{ Reasons not related to method:( $\mathrm{n}=29)$} \\
\hline Want to become pregnancy & 15 & 51.7 \\
\hline No/ infrequent sex-husband is not present & 14 & 48.3 \\
\hline \multicolumn{3}{|l|}{ Reasons related to method $(n=180)$} \\
\hline Method Failure & 16 & 8.9 \\
\hline Switch to another method & 16 & 8.9 \\
\hline Side effect & 93 & 51.7 \\
\hline Health concern & 20 & 11.1 \\
\hline Husband Disapproval & 20 & 11.1 \\
\hline Forgetting pills & 3 & 1.7 \\
\hline Lacking accessibility and availability & 12 & 6.6 \\
\hline
\end{tabular}

\section{DISCUSSION:}

It is well documented that effective family planning program can minimize unintended pregnancies, reduce maternal mortality, and improve child survival. To be successful, however, family planning program must motivate women to begin using contraception 
and must encourage women who are already using family planning not to discontinue contraceptive use (Khattaab, 2010).

Contraceptive discontinuations contribute substantially to the total fertility rate, unwanted pregnancies, and induced abortions. Among women who use contraceptives, many stop using them despite a continuing desire to avoid pregnancy; become pregnant while using contraception; or switch from highly effective contraceptive methods to less effective methods. Numerous reports in the past have focused on the levels, trends, and reasons why women do not use or do not intend to use contraceptives (e.g., Sedgh et al., 2007; Westoff, 2001; Westoff, 2006; Lutalo et al., 2000).

According to the study findings, more than two- thirds of the sample were below 35 years of age with a mean of $31.9 \pm 4.5$ years. This is opposite to Darweesh, (2011), who found that more than half of the sample were aged 20-30 years . Moreover, Vaughan et al., (2008) reported that age of the user continues to be a very important factor in the discontinuation of use. They found that $59.6 \%$ of women who discontinued their methods were in a younger age group, while $29.7 \%$ were in the middle age group and $10.7 \%$ were in the old age group. As for the reasons for discontinuation of contraceptive method, they were mainly method related reasons if the user was 20-30 years old, and less likely to be discontinued by women aged 30 years or more. Concerning the current discontinuation of IUD, the present study findings indicated that the desire for conception was at the top of the list, with the highest percentage of the reasons. This was followed by heavy bleeding and spotting. Women complained that they cannot pray, have sexual intercourse, perform household tasks or participate in community activities during menstruation. The above figures are very close to those reported by Alinany (2007) in Egypt.

Hormonal contraceptive users are more likely to say they have no need for contraception or to discontinue its use rather than to switch to modern or traditional methods. (The no-need category includes women who discontinue use of a method owing to the desire to become pregnant, method failure, separation, widowhood, and infecundity.) This result may be partly due to that many pill users are spacing births and may often discontinue them to have a child, but others who do not want pregnancy and are sexually active switch to long acting methods such as IUD, injectable or implanted hormone because they forget taking the pills regularly. The majority of switches from pills in the first year were to a more effective method. 
The menstrual side effects of hormonal contraceptive methods play in women's decisions to discontinue use of those methods. Over time, injectable users increasingly tended to miss menstrual periods $(2.4 \%)$, whereas implant users became less likely to do so, they experience irregular bleeding (1.2\%). Bleeding pattern dissatisfaction was the most common reason for premature discontinuation of hormonal contraceptives which is consistent with clinical trials and other audits (Mansour, et al., 2008). In the same line, the present result shows that more than two- thirds of the studied women discontinued hormonal contraceptive methods before the fifth year.

Similarly, Sparrow, (2004) added that there are disadvantages of hormonal contraception including 20\%-30\% of users experience spotting or breakthrough bleeding which tends to decrease with time, as there may be prolonged periods of amenorrhea. Moreover, there are small proportions of women's suffering from weight gain, loss of libido, acne, breast tenderness, headaches/dizziness, vaginal dryness, unintended pregnancy. Moreover, there are studies suggesting most functional ovarian cysts, and there are little or no effect on liver function, thyroid function and gastrointestinal function.

\section{CONCLUSION:}

\section{Based on study findings, it can be concluded that :}

Women requesting discontinuation of contraceptive methods had a mean age of 31.95 \pm 4.49 years, working and had higher level of education. Hormonal contraceptive methods "OCPs, injectable and implants" were the main contraceptive method used before discontinuation. Side effects of the IUD were the most common reason, with the highest percentage mostly due to menstrual irregularities, back or colicky pain and hyper-menorrhea. Side effects were the most common reason for the discontinuation of hormonal contraception followed by an equal percentage of health problems and husband disapproval. Husband' disapproval and failure of the method were the main reasons of discontinuation of mechanical barriers. However, the need to switch to another effective method was the most common reason for discontinuation of natural methods of family planning. Moreover, the majority of women intended to use another effective method of contraception.

\section{RECOMMENDATIONS:}

Based on the results of the present study, the following recommendations were suggested: Better training of health providers especially nurses to provide family planning services. Better information provision and counseling to clients, particularly about managing side effects and alternative contraceptive methods. More active promotion of IUD use, as one of the most effective contraceptives with the lowest failure and discontinuation rates. Ensuring quality services are available at all levels of the health system, particularly local level. Effective nursing program with the focus on the message that side effects of contraceptives 
are minor and temporary so that clients do not discontinue the method because of them. Greater efforts need to be made to encourage women to switch to modern methods rather than traditional methods and advice women about the importance of follow up care. Further research is proposed to assess the impact of counseling on reducing the rate of discontinuation of effective contraceptive methods.

\section{REFERENCES:}

Alanany H., (2007): Current state of intrauterine contraceptive devices. Department of Obstetrics and Gynecology, Cairo University, Egypt. Middle East Fertility Society Journal, $12(1) ; 8-12$.

Ali M. and Cleland, J., (2010). Oral contraceptive discontinuation and its aftermath in 19 developing countries. Contraception (81) p: 22-29.

Andrew J, (2005): Maryland family planning and reproductive health program. Maryland, Center for Maternal and Child Health.

Barden-O'Fallon J, Speizer I, CceresZelaya S, CixBorjas J, Rodriguez Valenzuela F,. (2008): Contraceptive discontinuation: A one-year follow-up study of female reversible method users in urban Honduras [working paper]. MEASURE Evaluation: Chapel Hill, NC.

Basavanthappa B.T. (2008): Community Health Nursing, 2nd edition, Jaypee publishers.New Delhi: pp.561-562.

Castledine G., Close A. (2004): Oxford Hand Book Of General Adult Nursing, 2nd ed , London ,Mosby:pp.564

Christensen B,L., Kockrow E.O.(2006): Adult Health Nursing ,5th ed ,Philadelphia, Mosby:pp.584-585

Cleland J., Bernstein S., Ezeh A., Faundes A., GIasier A., Innis J.(2006): Family Planning :the unfinished agenda . Lancet;368 (9549):99.1810-1827

Dardano KL. And Burkman RT., (2000): Contraceptive compliance. Obstet Gynecol Clin North Am (27) p: 933-941.

El-Zanaty and Ann Way, (2010): Egypt Demographic and Health Survey 2008 (Cairo: Ministry of Health, El-Zanaty and Associates, and Macro International: figure 6.1.

Farzaneh Roudi-Fahimi and Shereen El Feki, (2011): Facts of Life: Youth Sexuality and Reproductive Health in the Middle East and North Africa (Washington, DC: PRB). 
Freeman S. (2004): Non daily hormonal contraception: Considerations in contraception choice and patient Counseling. Journal of the American Academy of Nurse Practitioners; 16(6):pp.226-38

Galvao LW, Oliveira LC, Diaz, J, and et al., (2005): Effectiveness of female condom and male condom in preventing exposure to semen during vaginal intercourse: a randomized trial. Contraception; 71 p: 130-136.

Hassan E., El-Shafei M. (2004): Manual of Safe Reproductive health, 2 nd ed., Mansoura, pp.81-90

Moreau C, Cleland K. and Trussell J., (2007): Contraceptive discontinuation attributed to method dissatisfaction in the United States. Contraception 76 p: 267-272.

Nguyen T.H., Park M.H. and Lem H (2011): The dynamics of Intrauterine device (IUD) use among Vietnamese women, located at http/www.google.com, accessed at May 6/2013. No. 55.Baltimore, INFO Project, Johns Hopkins Bloomberg School of Public Health, March.

Olds S.,London M.,LadewigP.,Davidson M.(2004):Maternal-Newborn nursing \& women's health care , seventh ed., Pearson Prentice Hall company, upper saddle river ,New Jersey:pp.98-99

Trussell J, Lalla AM, and Doan QV, et al, (2009): Cost effectiveness of contraceptives in the United States. Contraception 79 p: 514.

Vaughan B, Trussell J, Kost K, Singh S, and Jones R, (2008): Discontinuation and resumption of contraceptive use: results from the 2002 National Survey of Family Growth. Contraception 78 p: 271-283.

Westoff, $\boldsymbol{C F}$, (2001): Unmet need at the end of the century DHS Comparative Reports No. 1. Calverton, Maryland: ORC Macro. 


\section{أسباب التوقف عن أستخدام وسائل منع الحمل فى مدينة بورسعيد}

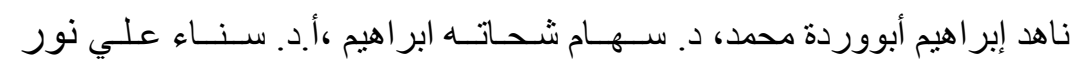

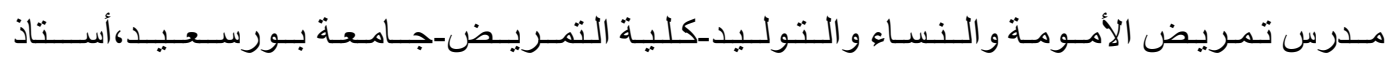

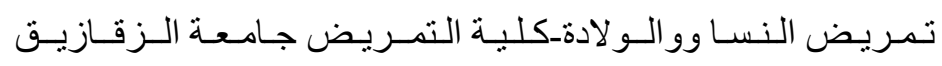

\section{الـخـلاصــة}

معظم حالات الحمل في مصر غير مقصودة. منها عدد كبير يحدث للنساء الاتى كانو ا يمارسن وسائل منع الحمل

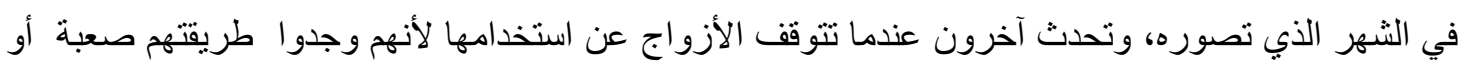
غير مريحة عند الاستخدام. هدف هذه الدراسة هو إيجاد أسباب التوقف عن أستخدام وسائل منع الحمل في مدينة بورسعيد. وقد أجريت هذه الدراسة في خمس مر اكز تنظيم الأسرة و هم مركز العرب ،الكويت، المناخ، عثمان إبن

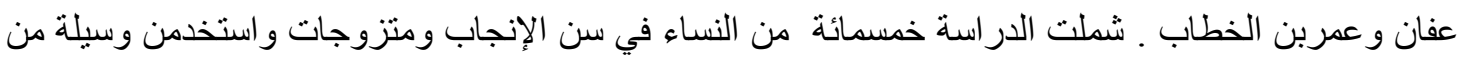
وسائل منع الحمل. وأظهرت النتائج أن (39.2٪) من النساء قد استخدمن وسائل منع الحمل الهرموني قبل التوقف، وكان سبب التوقف في الغالب بسبب الآثار الجانبية (51.7٪) تليها نسبة منساوية من مشاكل صحية حدثت لهاو رفض زوجها (11.1\%). وفي الوقت نفسه (21.6٪) تستخدم اللولب قبل التوقف وكان سبب التوقق

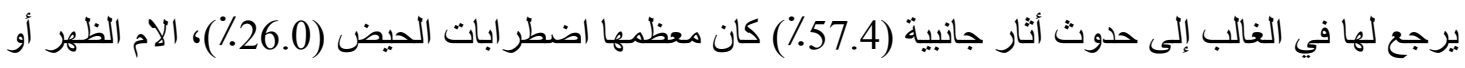
المغص (39.0\%) وفرط الطمث(35.0 \%).. و الجدير بالذكر أن الأسباب الرئيسية للانقطاع عن أستخدام الحواجز الميكانيكية كانت رفض الزوج (28.7\%) وفنشل الوسيلة(15.1\%) .أما كانت الحاجة للتبديل إلى طريقة فعالة أخرى بنسبة (33.3\%) كان السبب الأكثر شيو عا لانقطاع عن أستخدام الطرق الطبيعية فى منع الحمل . وأوصت الدراسة أن أفضل تدريب هو لمقدمي الخدمات الصحية وخاصة الممرضات لتقديم خدمات تنظيم الأسرة، وتوفير معلومات أفضل وتقديم المشورة للعملاء، وخاصة حول إدارة الآثار الجانبية وسائل منع الحمل لثل البديلة.الصحيحة عن الوسائل المختلفة ومعالجة أسباب الأنقاع عن الوسيلة بسبب الأعر اض الجانبية وتوفير الكفأة الطبية من كو ادر وأجهزة بمر اكز تنظيم الأسرة. 